\title{
Analisis Karakteristik Busur Api Listrik Tegangan Rendah pada Hubung Singkat Langsung melalui Sinkronisasi Penginderaan Termal Bunga Api dan Arus Hubung Singkat
}

\author{
Rifki Wiryatama, Dimas Anton Asfani, dan Daniar Fahmi \\ Jurusan Teknik Elektro, Fakultas Teknologi Industri, Institut Teknologi Sepuluh Nopember (ITS) \\ Jl. Arief Rahman Hakim, Surabaya 60111 \\ e-mail: anton@ee.its.ac.id, daniarfahmi.elits@gmail.com
}

\begin{abstract}
Abstrak- Salah satu bahaya yang bisa timbul akibat penggunaan listrik adalah gangguan hubung singkat yang bisa menimbulkan busur api listrik dan memicu terjadinya kebakaran. Kasus kebakaran yang disebabkan oleh hubung singkat listrik pada tegangan rendah meningkat setiap tahun. Pada beberapa kasus, kebakaran pada instalasi tegangan rendah disebabkan oleh adanya gangguan hubung singkat yang tidak menyebabkan putusnya fuse pengaman atau breaker yang diawali dengan munculnya busur api listrik. Dalam eksperimen ini akan dilakukan simulasi kejadian hubung singkat pada kabel serabut tegangan rendah ukuran $1.5 \mathrm{~mm}^{2}$, dengan variasi jumlah serabut yang mengalami kontak. Ketika busur api listrik terjadi, arus dan tegangan busur api akan direkam. Selain itu, dalam waktu yang sama, proses terjadinya busur api listrik akan direkam melalui kamera termal. Data arus dan tegangan akan disinkronisasikan dengan data hasil pencitraan busur api listrik pada kamera termal. Hasil sinkronisasi ini akan dianalisa, sehingga dapat menghasilkan suhu maksimum busur api, data luas busur api, waktu peluruhan suhu busur api, arus maksimum ketika terjadi busur api, dan durasi terjadinya gangguan hubung singkat. Hasil studi ini diharapkan dapat membantu pembuatan alat proteksi busur api listrik tegangan rendah pada penelitian selanjutnya.
\end{abstract}

Kata Kunci-Busur Api Listrik Tegangan Rendah, Karakteristik Busur Api Listrik, Kamera Termal.

\section{PENDAHULUAN}

$\mathrm{P}$ ENGGUNAAN listrik merupakan kebutuhan utama dalam kehidupan manusia, baik pada sektor rumah tangga, penerangan, komunikasi, industri dan lain sebagainya. Salah satu bahaya akibat penggunaan listrik adalah bahaya kebakaran akibat hubung singkat atau sering disebut korsleting. Dibutuhkan sistem keamanan yang lebih handal dalam penggunaan listrik yang besar untuk mengurangi resiko terjadinya kebakaran. Kasus kebakaran yang diakibatkan hubung singkat setiap tahunnya meningkat. Berdasarkan data Badan Nasional Penanggulangan Bencana (BNPB) periode Agustus 2011 sampai dengan April 2015 dari 973 kasus kebakaran yang terjadi di pemukiman penduduk 644 diantaranya disebabkan oleh hubung singkat arus listrik yang disertai peristiwa busur api listrik. Hubung singkat adalah proses terjadinya kontak antara dua titik yang memiliki beda potensial yang mengakibatkan melonjaknya arus listrik yang menyebabkan kenaikan suhu secara drastis pada konduktor. Jika kabel tidak mampu menopang nilai arus yang lewat, maka kabel bisa terbakar atau juga bisa timbul busur api. Dapat dikatakan bahwa gangguan hubung singkat pada sistem tegangan rendah yang menimbulkan busur api listrik sering kali tidak terdeteksi oleh sekring pengaman atau MCB. Hal ini dapat terjadi pada kabel atau konduktor tegangan rendah yang mengalami kerusakan isolasi karena pemanasan, penuaan, ataupun karena gangguan eksternal lain seperti dimakan binatang pengerat.

Dalam studi ini akan dibahas beberapa permasalahan yaitu mengenai bagaimana mekanisme terjadinya busur api listrik, karakteristik busur api listrik, dan pengaruh jumlah serabut konduktor terhadap karakteristik busur api listrik yang terjadi pada hubung singkat langsung tegangan rendah. Dalam studi ini, dilakukan eksperimen busur api listrik dengan menggunakan suatu perangkat hubung-singkat buatan. Masalah dalam studi ini dibatasi pada analisis yang dilakukan terhadap hasil eksperimen busur api listrik tegangan rendah pada kabel serabut $1.5 \mathrm{~mm}^{2}$ dengan beban resistif. Hasil eksperimen berupa arus, tegangan, dan citra termal bunga api listrik diolah hingga didapatkan karakteristik berupa suhu maksimum busur api, luas busur api, waktu peluruhan suhu busur api, arus maksimum ketika terjadi arcing, dan durasi gangguan busur api. Sedangkan tujuan dari eksperimen ini adalah untuk mengetahui karakteristik busur api listrik yang menyebabkan letupan bunga api yang menyebar ke segala arah. Dari karakteristik ini, akan diketahui fenomenafenomena yang terjadi selama busur api listrik berlangsung.

Metode yang digunakan dalam studi ini, yang pertama adalah melakukan studi literatur dan persiapan data mengenai analisis karakteristik busur api listrik tegangan rendah pada hubung singkat langsung. Setelah mengumpulkan data-data yang dibutuhkan maka selanjutnya adalah pembuatan alat eksperimen busur api listrik berupa seperangkat alat hubung singkat langsung buatan. Kemudian langkah selanjutnya adalah melakukan eksperimen busur api listrik. Ketika busur api listrik terjadi, data arus, tegangan dan citra bergerak dari bunga api akan direkam. Setelah melakukan eksperimen, maka langkah selanjutnya adalah melakukan pengolahan data hasil eksperimen. Pada pengolahan data, data arus-tegangan, dan suhu akan disinkronisasikan dengan data citra termal bunga 
api. Kemudian langkah terakhir adalah hasil dari pengolahan data dianalisis karakteristiknya dengan mempertimbangkan pengaruh jumlah serabut konduktor kabel.

\section{KARAKTERISTIK BUSUR API LISTRIK}

Percikan, intensitas panas yang tinggi, dan partikel pembakaran dihasilkan dari proses terjadinya arc flash. Ketika dua permukaan konduktif mendekat secara bersamaan dan diikuti lompatan arus yang melewati sela antara konduktor akan terjadi hubung singkat diikuti oleh percikan listrik karena nilai yang cukup dan udara disekitar menjadi konduktif akibat ionisasi yang terjaga dengan baik selanjutnya akan menimbulkan busur api listrik [1]. Hubung singkat menyebabkan kabel terbakar atau juga bisa terjadi arc flash, karena pelonjakan arus listrik disertai kenaikan suhu secara drastis pada konduktor dan pada akhirnya kabel tidak mampu menopang nilai arus yang lewat

Arc flash memproduksi plasma hasil ionisasi dari konduktor. Menurut NFPA arc flash merupakan sebuah pelepasan energi termal dan cahaya oleh penguapan dan ionisasi dari sebuah material, yang dapat mencapai suhu sampai $35.000^{\circ} \mathrm{F}$ [2]. Jika arc flash terpapar pada kulit akan menimbulkan bahaya yaitu luka bakar. Kebakaran dapat dipicu jika lelehan logam yang tersebar akibat arc flash ini mengalami kontak dengan benda yang mudah terbakar, seperti kain tekstil, kertas pada tempat, situasi, dan waktu yang tidak dikehendaki yang bersifat merugikan dan pada umumnya sulit untuk dikendalikan. Arc flash akan lebih berbahaya jika kontak dengan bahan yang dapat menimbulkan ledakan yang mengancam nyawa disekitarnya.

Peralatan listrik yang sering mengalami kerusakan isolasi adalah kabel. Kabel memiliki potensi terjadinya busur api listrik pada tegangan rendah, karena gangguan impedansi tinggi yang tidak dapat dideteksi oleh perangkat pengaman, dapat terjadi akibat pengaruh media saluran maupun media hubung singkat. Setiap jenis kabel memiliki spesifikasi Kuat Hantar Arus (KHA) yaitu arus nominal yang dapat dihantarkan pada kabel. Spesifikasi KHA pada kabel juga bergantung pada luas penampang kabel. Kabel konduktor yang digunakan pada perangkat tegangan rendah biasanya jenis serabut dan ukuran penampang kabel konduktor memiliki ukuran penampang yang bermacam-macam. Kabel $1.5 \mathrm{~mm}^{2}$ biasanya paling sering digunakan dan dipasang pada area perumahan atau permukiman. Kabel serabut $1.5 \mathrm{~mm}^{2}$ memiliki KHA nominal sebesar 10A. Artinya, kabel $1.5 \mathrm{~mm}^{2}$ mampu menghantarkan arus sampai dengan 10A [3]. Arus listrik yang melebihi KHA dari suatu kabel akan menyebabkan kabel tersebut menjadi panas dan bila melebihi daya tahan isolasinya, maka dapat menyebabkan rusaknya isolasi. Kerusakan isolasi bisa menyebabkan kebocoran arus listrik dan akibatnya bisa fatal seperti kesetrum pada manusia atau bahkan mengakibatkan terjadinya kebakaran.

Kasus kebakaran yang terjadi karena adanya hubung singkat yang diikuti dengan peristiwa busur api listrik dalam kurun waktu 2011 sampai dengan 2015, lebih dari 65\% [4]. Umumnya kebakaran terjadi di pemukiman padat penduduk yang rentan terjadi korsleting listrik (hubung singkat listrik) karena instalasi listrik yang cenderung tertata tidak rapi dan kemungkinan terjadi hubung singkat sangat tinggi.Nilai arus yang besar ketika terjadi busur api listrik ternyata tidak bisa membuat perangkat pengaman listrik konvensional seperti MCB (Miniature Circuit Breaker) atau Sekering Otomatis (Automatic Fuse) pada perumahan dan pemukiman memutus rangkaian utama. Hal ini dikarenakan durasi terjadinya hubung singkat tidak cukup untuk membuat peralatan pengaman trip [5].

Dalam beberapa kasus hubung singkat, arus hubung singkat ternyata tidak menimbulkan putusnya fuse atau terbukanya breaker. Smoak dan Keeth [6] melakukan eksperimen hubung singkat pada trafo $50 \mathrm{kVA}$ dan $167 \mathrm{kVA}$ dengan rating tegangan $240 \mathrm{~V}$. Hasilnya adalah hubung singkat non-bolted dengan panjang arc yang bervariasi tidak menyebabkan meleburnya fuse, atau pengaman arus tidak bekerja.

Pada saat busur api listrik berlangsung, akan mengalir arus yang tinggi dan mengandung unsur noise $(10 \mathrm{kHz}-1 \mathrm{GHz})$ [7]. Arus yang tinggi menyebabkan tegangan menurun saat busur api listrik terjadi. Arus busur api listrik memiliki fase dimana nilainya seolah-olah bernilai nol (intermittent). Hal ini hanya terjadi ketika busur api listrik terjadi. Ketika gangguan yang terjadi hubung singkat tanpa busur api listrik, karakteristik intermittent pada arus tidak ada. Nilai tegangan turun pada saat terjadi busur api listrik dan terdapat sedikit cacat pada tegangannya [8]. Sedangkan untuk karakteristik energi besarnya tergantung pada arus dan waktu. Semakin besar arus dan durasi busur api listrik, energi yang dikonsumsi akan semakin besar. Selanjutnya, arus yang nilainya besar akan menyebabkan frekuensi terjadinya busur api listrik lebih banyak sehingga total energi yang dikonsumsi akan semakin lebih besar [9].

Api merupakan bencana yang mengancam setiap manusia. Api dapat menyebabkan kebakaran yang besar apabila terjadi di pemukiman padat penduduk. Sumber potensi penyebab kebakaran secara umum yaitu peralatan listrik yang tidak memenuhi syarat keamanan (PUIL), pembebanan lebih, tegangan melebihi kapasitas, dan munculnya bunga api. Nyala api pada hakekatnya masa zat yang sedang berpijar yang dihasilkan didalam proses kimia oksidasi yang berlangsung secara cepat dan disertai pelepasan energi atau panas. Ada tiga unsur yang menyebabkan terbentuknya api yaitu oksigen, panas, dan bahan bakar [10]. Bahan bakar cair yang memiliki titik nyala dibawah $78^{\circ} \mathrm{F}\left(22,8^{\circ} \mathrm{C}\right)$ dan memiliki titik bakar pada atau diatas $100^{\circ} \mathrm{F}\left(37,8^{\circ} \mathrm{C}\right)$ diantaranya aseton, benzena, dan bensin [11].

Penginderaan termal ini menggunakan radiasi inframerah yang artinya tidak dapat dilihat oleh mata telanjang. Untuk melakukan penginderaan citra termal arcing ini, maka dibutuhkan piranti perekam citra termal yang mampu merekam fenomena arcing. Pencitraan termal atau yang disebut dengan thermography, adalah teknik menghasilkan gambar dari radiasi inframerah, dapat dikatakan tidak dapat dilihat oleh mata manusia. Kamera termal memiliki sensor yang berfungsi untuk menangkap pancaran atau pantulan radiasi termal dari objek. Gambar termal yang dihasilkan oleh kamera ini disebut 
sebagai thermograms, dimana setiap piksel gambar sesuai dengan nilai digital dan sebanding dengan jumlah energi yang diterima [12].

\section{EKSPERIMEN BUSUR API LISTRIK TEGANGAN RENDAH}

\section{A. Eksperimen}

Perancangan alat eksperimen busur api listrik secara paralel ini bertujuan untuk mensimulasikan fenomena terjadinya busur api listrik secara langsung. Skema rangkaian eksperimen ditunjukkan oleh Gambar 1.

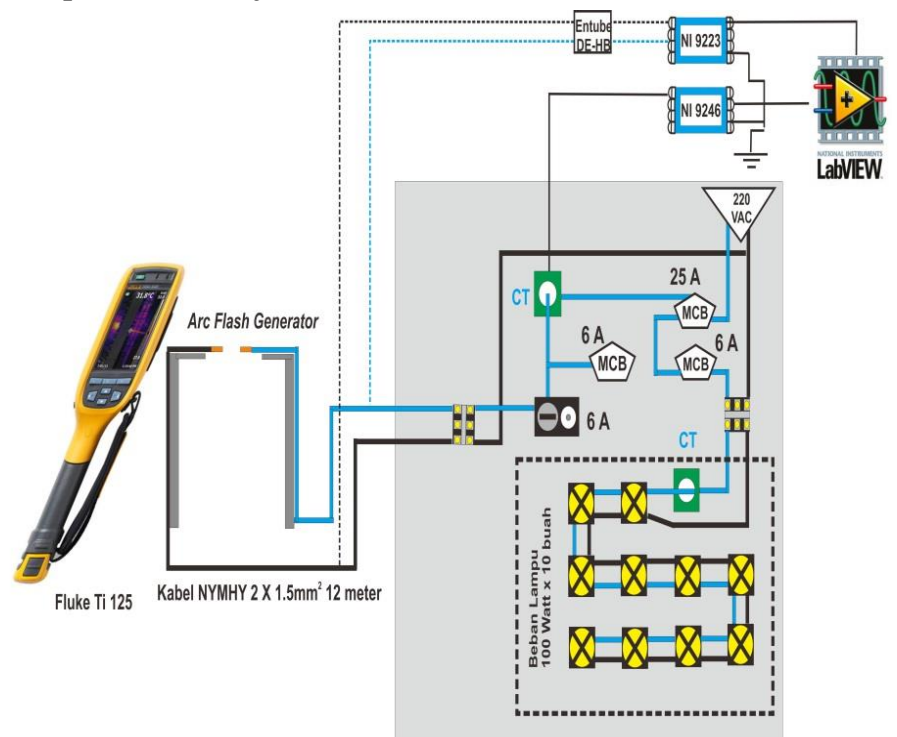

Gambar 1. Skema alat eksperimen busur api listrik pada tegangan rendah

Rangkaian eksperimen busur api listrik terdiri dari hardware dan software. Hardware yang digunakan adalah sekering otomatis (fuse) 6A, fuse box, current transformer (CT) 200/5 A, kabel tembaga serabut 1 fasa ukuran penampang $1,5 \mathrm{~mm}^{2}$ (NYMHY $2 \times 1,5 \mathrm{~mm}^{2}$ ), beban resistif berupa lampu 100 watt sebanyak 10 buah, chamber kamera yang terbuat dari akrilik, Fluke Ti 125 sebagai perekam citra termal bunga api, NI 9246 sebagai perekam arus, dan NI 9223 sebagai perekam tegangan dengan bantuan sensor tegangan Verivolt Entube DE-HB. Sedangkan software yang mendukung alat eksperimen ini adalah software LabVIEW yang telah disinkronkan dengan fitur DAQ Assist, untuk human interface sekaligus sebagai akuisisi data saat proses pengambilan data berlangsung. Eksperimen dilakukan sebanyak 5 kali untuk satu variasi jumlah serabut. Artinya, dalam eksperimen ini akan ada eksperimen sebanyak 25 kali.

\section{B. Pengolahan Data}

Arus dan tegangan arcing pada saat fenomena busur api listrik terjadi, akan diolah menggunakan software penunjang DIAdem. Citra termal bergerak bunga api akan diolah menggunakan VLC Frame Extractor, sehingga didapatkan data scene tiap framenya. Luas daerah dari arcing akan diolah dengan cara perhitungan luasan dari suatu daerah. Sinkronisasi citra termal bunga api dan arus hubung singkat akan diolah menggunakan Microsoft Power Point. Pengolahan data bertujuan untuk memperoleh karakteristik busur api berupa nilai arus maksimum, fault duration, maximum temperature arc flash, temperature decay period, dan luas busur api atau arc flash area.

\section{HASIL DAN ANALISIS}

\section{A. Perekaman Data Arus, Tegangan, Suhu, dan Citra Bergerak Bunga Api}

Pada ekesperimen ini kamera termal Fluke Ti 125 digunakan sebagai perekam fenomena busur api listrik yang menghasilkan produk berupa kilatan cahaya (flash) dengan intensitas yang tinggi, percikan api (spark), dan lelehan serabut konduktor yang menyebar ke segala arah akibat ekspansi tekanan udara yang besar dalam waktu yang singkat. Mode yang digunakan untuk perekaman menggunakan IR (infrared) minimum, karena mode ini memperlihatkan gambar real dan termal dari suatu objek. Proses terjadinya busur api listrik yang terekam oleh kamera termal mulai dari kontak (a), flash (b), dan spark \& debris (c) ditunjukkan oleh Gambar 3.
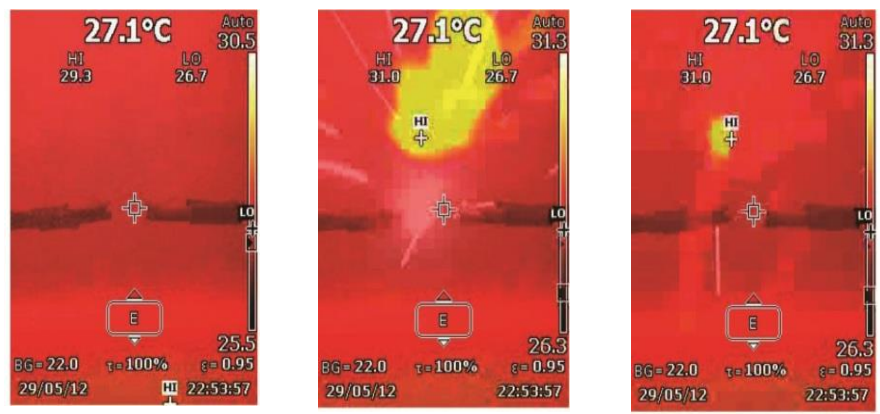

Gambar 2. Proses terjadinya busur api listrik yang terekam oleh kamera termal, ketika terjadi kontak (a), flash (b), dan debris (c)

\section{B. Analisis Karakteristik}

Analisis karakteristik busur api listrik api listrik pada tegangan rendah meliputi analisis beberapa parameter seperti shu maksimum busur api, luas dari busur api, waktu peluruhan suhu busur api, arus, tegangan, durasi dan citra termal dari busur api listrik yang terjadi. Analisis dilakukan dengan mempertimbangkan pengaruh variasi jumlah serabut yang digunakan. Citra termal yang didapatkan pada eksperimen busur api listrik merupakan konten utama dalam eksperimen ini. Dari kumpulan citra statik ini, akan diketahui bagaimana bentuk sinyal arus, tegangan, dan suhu ketika kejadian hubung singkat berlangsung mulai dari kontak, flash, sparking, sampai lelehnya kabel konduktor.

\section{Arc Flash Maximum Temperature}

Arc flash maximum temperature merupakan suhu maksimum dari busur api ketika fault terjadi. Apabila terjadi perubahan suhu yang sangat cepat, maka kamera termal akan mengalami proses calibrating. Proses calibrating pada kamera termal merupakan proses penyesuaian suhu yang terekam pada kamera termal sesuai dengan suhu ruang, emisivitas, dan suhu dari suatu objek yang diukur. Untuk mempermudah penyajian 
dalam bentuk grafik, suhu yang bernilai $>85^{\circ} \mathrm{C}$ diasumsikan bernilai $100^{\circ} \mathrm{C}$. Tabel 1 data arc flash maximum temperature.

Tabel 1.

Data arc flash maximum temperature yang terekam selama eksperimen

\begin{tabular}{|c|c|c|c|c|c|}
\hline $\begin{array}{c}\text { Percobaan } \\
\text { ke- }\end{array}$ & $\begin{array}{c}1 \\
\text { serabut }\end{array}$ & $\begin{array}{c}3 \\
\text { serabut }\end{array}$ & $\begin{array}{c}6 \\
\text { serabut }\end{array}$ & $\begin{array}{c}12 \\
\text { serabut }\end{array}$ & $\begin{array}{c}24 \\
\text { serabut }\end{array}$ \\
\hline 1 & $69.8^{\circ} \mathrm{C}$ & $54.7^{\circ} \mathrm{C}$ & $65.3^{\circ} \mathrm{C}$ & $56.4^{\circ} \mathrm{C}$ & $75.9^{\circ} \mathrm{C}$ \\
\hline 2 & $67.3^{\circ} \mathrm{C}$ & $\begin{array}{l}>85.0^{\circ} \mathrm{C} \\
\left(100^{\circ} \mathrm{C}\right)\end{array}$ & $84.6^{\circ} \mathrm{C}$ & $\begin{array}{l}>85.0^{\circ} \mathrm{C} \\
\left(100^{\circ} \mathrm{C}\right)\end{array}$ & $\begin{array}{c}>85^{\circ} \mathrm{C} \\
\left(100^{\circ} \mathrm{C}\right)\end{array}$ \\
\hline 3 & $68.2^{\circ} \mathrm{C}$ & $63.0^{\circ} \mathrm{C}$ & $\begin{array}{l}62.9^{\circ} \mathrm{C} \\
>85^{\circ} \mathrm{C}\end{array}$ & $78.8^{\circ} \mathrm{C}$ & $49.2^{\circ} \mathrm{C}$ \\
\hline 4 & $63.3^{\circ} \mathrm{C}$ & $46.9^{\circ} \mathrm{C}$ & $\begin{array}{c}\left(100^{\circ} \mathrm{C}\right) \\
>85^{\circ} \mathrm{C}\end{array}$ & $\begin{array}{c}54.6^{\circ} \mathrm{C} \\
>85.0\end{array}$ & $\begin{array}{r}65.0^{\circ} \mathrm{C} \\
>85^{\circ} \mathrm{C}\end{array}$ \\
\hline 5 & $53.3^{\circ} \mathrm{C}$ & $50.2^{\circ} \mathrm{C}$ & $\left(100^{\circ} \mathrm{C}\right)$ & $\left(100^{\circ} \mathrm{C}\right)$ & $\left(100^{\circ} \mathrm{C}\right)$ \\
\hline
\end{tabular}

Dari Tabel 1, dapat diamati ternyata variasi jumlah serabut memiliki pengaruh terhadap nilai arc flash maximum temperature. Semakin banyak jumlah serabut yang mengalami kontak, maka semakin besar nilai arc flash maximum temperature. Nilai suhu maksimum pada 6, 12, dan 24 serabut hampir linier.

\section{Arc Flash Area}

Hubung singkat menghasilkan busur api yang memiliki luas dan bentuk yang berbeda-beda. Pada eksperimen ini variasi jumlah serabut mempengaruhi luas dari busur api yang terekam pada kamera termal. Luas dari busur api ini disebut arc flash area. Cara yang digunakan dalam pengukuran luas busur api sama seperti menghitung luas suatu daerah pada peta. Karena bentuk dari busur api menyerupai daerah atau pulau pada peta. Penentuan luas busur api dengan menggunakan angka 1 dan 1/2 yang nantinya diisi pada kotak yang telah dibuat secara manual berukuran $1 \mathrm{~mm}^{2}$. Maksud dari penggunaan angka 1 dan 1/2 adalah jika daerah busur api memenuhi satu kotak penuh template yang telah dibuat, maka diberikan angka 1. Jika daerah busur api hanya memenuhi setengah dari kotak, maka diberikan angka 1/2. Selanjutnya dihitung luas total daerah 1 dan luas total daerah $1 / 2$, maka akan didapatkan total dari luas busur api setelah menjumlahkan luas daerah bernilai 1 dan luas daerah bernilai $1 / 2$. Data arc flash area pada eksperimen ditunjukkan pada Tabel 2.

Tabel 2.

Data arc flash area yang terekam selama eksperimen

\begin{tabular}{|c|c|c|c|c|c|}
\hline $\begin{array}{c}\text { Percobaan } \\
\text { Ke- }\end{array}$ & $\begin{array}{c}1 \\
\text { serabut }\end{array}$ & $\begin{array}{c}3 \\
\text { serabut } \\
\end{array}$ & $\begin{array}{c}6 \\
\text { serabut } \\
\end{array}$ & $\begin{array}{c}12 \\
\text { serabut }\end{array}$ & $\begin{array}{c}24 \\
\text { serabut }\end{array}$ \\
\hline 1 & $630 \mathrm{~mm}^{2}$ & $800 \mathrm{~mm}^{2}$ & $1330 \mathrm{~mm}^{2}$ & $221 \mathrm{~mm}^{2}$ & $268 \mathrm{~mm}^{2}$ \\
\hline 2 & $443 \mathrm{~mm}^{2}$ & $644 \mathrm{~mm}^{2}$ & $1360 \mathrm{~mm}^{2}$ & $435 \mathrm{~mm}^{2}$ & $154 \mathrm{~mm}^{2}$ \\
\hline 3 & $502 \mathrm{~mm}^{2}$ & $538 \mathrm{~mm}^{2}$ & $528 \mathrm{~mm}^{2}$ & $112 \mathrm{~mm}^{2}$ & $418 \mathrm{~mm}^{2}$ \\
\hline 4 & $247 \mathrm{~mm}^{2}$ & $632 \mathrm{~mm}^{2}$ & $1189 \mathrm{~mm}^{2}$ & $300 \mathrm{~mm}^{2}$ & $257 \mathrm{~mm}^{2}$ \\
\hline 5 & $410 \mathrm{~mm}^{2}$ & $556 \mathrm{~mm}^{2}$ & $1224 \mathrm{~mm}^{2}$ & $228 \mathrm{~mm}^{2}$ & $804 \mathrm{~mm}^{2}$ \\
\hline
\end{tabular}

Dari Tabel 2, dapat diamati ternyata variasi jumlah serabut memiliki pengaruh terhadap nilai arc flash area. Pada jumlah serabut sedikit 1, 3, dan 6 serabut, nilai arc flash area semakin besar. Sedangkan pada jumlah serabut banyak 12 dan 24 serabut, nilai arc flash area bertambah kecil.

\section{Temperature Decay Period}

Temperature decay period merupakan waktu yang dibutuhkan suhu maksimum dari busur api untuk meluruh sampai kontak antar serabut berakhir. Karena suhu yang tinggi berpotensi menyebabkan api dan kebakaran. Pada temperature decay period, nilai suhu yang digunakan sebagai threshold sebesar $50^{\circ} \mathrm{C}$. Nilai titik bakar (fire point) dari bahan bakar cair seperti bensin, kerosin, dan sebagainya berkisar $50^{\circ} \mathrm{C}$. Menurut NFPA dan Peraturan Khusus EE bahan yang mempunyai titik nyala (flash point) kurang dari $55^{\circ} \mathrm{C}$ celcius merupakan bahan yang mudah terbakar atau memiliki resiko tinggi. Tabel 3 menunjukkan nilai arc ignition current yang terjadi ketika kabel mengalami kontak. Nilai arus yang tertera memiliki satuan ampere.

Tabel 3.

Data temperature decay period pada eksperimen

\begin{tabular}{cccccc}
\hline \hline $\begin{array}{c}\text { Percobaan } \\
\text { ke- }\end{array}$ & $\begin{array}{c}1 \\
\text { serabut }\end{array}$ & $\begin{array}{c}3 \\
\text { serabut }\end{array}$ & $\begin{array}{c}6 \\
\text { serabut }\end{array}$ & $\begin{array}{c}12 \\
\text { serabut }\end{array}$ & $\begin{array}{c}24 \\
\text { serabut }\end{array}$ \\
\hline 1 & $2.5 \mathrm{~ms}$ & $5.9 \mathrm{~ms}$ & $12 \mathrm{~ms}$ & $>10 \mathrm{~s}$ & $>10 \mathrm{~s}$ \\
2 & $2.8 \mathrm{~ms}$ & $7.5 \mathrm{~ms}$ & $14.2 \mathrm{~ms}$ & $>10 \mathrm{~s}$ & $5.28 \mathrm{~s}$ \\
3 & $2.8 \mathrm{~ms}$ & $6.8 \mathrm{~ms}$ & $2.9 \mathrm{~ms}$ & $6.025 \mathrm{~s}$ & $>10 \mathrm{~s}$ \\
4 & $2.7 \mathrm{~ms}$ & $\mathrm{n} / \mathrm{a}^{*}$ & $78.2 \mathrm{~ms}$ & $>10 \mathrm{~s}$ & $7.026 \mathrm{~s}$ \\
5 & $1.6 \mathrm{~ms}$ & $0.3 \mathrm{~ms}$ & $190 \mathrm{~ms}$ & $6.5 \mathrm{~s}$ & $>10 \mathrm{~s}$ \\
\hline \hline
\end{tabular}

*) tidak mengalami temperature decay period

\section{Arus Maksimum}

Arus maksimum merupakan arus tertinggi yang terjadi ketika hubung singkat atau fault. Dengan menggunakan DIAdem untuk menentukan arus maksimum digunakan fitur max absolute coordinate dan min absolute coordinate. Grafik sinyal arus pada DIAdem memiliki koordinat X dan Y dengan menggunakan max absolute coordinate dan min absolute coordinate maka secara otomatis akan menemukan arus tertinggi pada grafik sinyal arus arc. Penentuan arus maksimum dapat juga menggunakan crosshair cursor, namun cara menggunakannya secara manual. Gambar 4.10 menunjukkan grafik arus maksimum menggunakan max absolute coordinate dan min absolute coordinate. Data arus maksimum yang terekam pada saat eksperimen ditunjukkan pada Tabel 4.
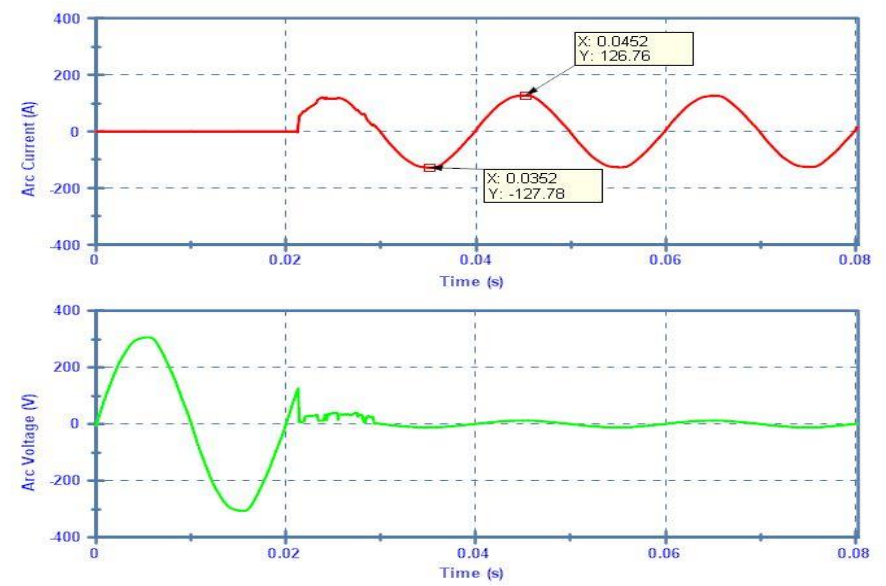

Gambar 3. Grafik arus maksimum menggunakan max \& min absolute coordinate 
Tabel 4.

Data arus maksimum yang terekam selama eksperimen

\begin{tabular}{cccccc}
\hline \hline $\begin{array}{c}\text { Percobaan } \\
\text { ke- }\end{array}$ & $\begin{array}{c}1 \\
\text { serabut }\end{array}$ & $\begin{array}{c}3 \\
\text { serabut }\end{array}$ & $\begin{array}{c}6 \\
\text { serabut }\end{array}$ & $\begin{array}{c}12 \\
\text { serabut }\end{array}$ & $\begin{array}{c}24 \\
\text { serabut }\end{array}$ \\
\hline 1 & 103.97 & 114.97 & 116.12 & 127.78 & 128.45 \\
2 & 113.99 & 111.69 & 115.26 & 125.60 & 115.32 \\
3 & 104.90 & 111.75 & 115.87 & 126.38 & 126.94 \\
4 & 104.57 & 125.10 & 114.49 & 126.81 & 126.30 \\
5 & 114.30 & 115.01 & 115.17 & 127.46 & 126.90 \\
\hline \hline
\end{tabular}

\section{Fault Duration}

Dari hasil eksperimen serabut dengan jumlah yang sedikit memiliki fault duration yang singkat rata- rata 6,49 milisekon. Sedangkan hasil eksperimen dengan jumlah serabut yang banyak memiliki rata-rata fault duration lebih dari 1,5 sekon. Tabel 5 menunjukkan fault duration selama eksperimen berlangsung.

Tabel 5.

Data durasi fault pada eksperimen

\begin{tabular}{cccccc}
\hline \hline $\begin{array}{c}\text { Percobaan } \\
\text { Ke- }\end{array}$ & $\begin{array}{c}1 \\
\text { serabut }\end{array}$ & $\begin{array}{c}3 \\
\text { serabut }\end{array}$ & $\begin{array}{c}6 \\
\text { serabut }\end{array}$ & $\begin{array}{c}12 \\
\text { serabut }\end{array}$ & $\begin{array}{c}24 \\
\text { serabut }\end{array}$ \\
\hline 1 & $5 \mathrm{~ms}$ & $8.2 \mathrm{~ms}$ & $20 \mathrm{~ms}$ & $\begin{array}{c}1,250.40 \\
\mathrm{~ms}\end{array}$ & $>10 \mathrm{~s}^{*}$ \\
2 & $6.6 \mathrm{~ms}$ & $10 \mathrm{~ms}$ & $20.3 \mathrm{~ms}$ & $\begin{array}{c}486.22 \mathrm{~ms} \\
157.5 \mathrm{~ms}\end{array}$ & \\
3 & $9.8 \mathrm{~ms}$ & $7.8 \mathrm{~ms}$ & $6.8 \mathrm{~ms}$ & $\begin{array}{c}563.02 \mathrm{~ms} \\
2594.12\end{array}$ & $>10 \mathrm{~s}^{*}$ \\
4 & $8.1 \mathrm{~ms}$ & $17 \mathrm{~ms}$ & $60 \mathrm{~ms}$ & $\begin{array}{c}\mathrm{ms} \\
1552.20\end{array}$ & $>10 \mathrm{~s}^{*}$ \\
5 & $5 \mathrm{~ms}$ & $5.1 \mathrm{~ms}$ & $174.2 \mathrm{~ms}$ & $\mathrm{~ms}^{*}$ & $168.9 \mathrm{~ms}$ \\
\hline \hline
\end{tabular}

*) fuse mengalami trip

\section{Fuse Trip}

Selama proses pengambilan data, pada eksperimen dengan jumlah serabut yang banyak sempat mengalami fuse trip. Serabut dengan jumlah 12 mengalami trip dua kali yaitu pada percobaan ke-4 dan ke-5. Sedangkan serabut dengan jumlah 24 mengalami trip sebanyak 3 kali yaitu pada percobaan ke-1, percobaan ke-3, dan percobaan ke-4. Serabut dengan jumlah 12 pada percobaan ke-4 dan ke-5 rata-rata memiliki fault duration lebih dari satu detik yaitu sebesar 2.073,16 detik. Serabut dengan jumlah 24 pada percobaan ke-1, 3, dan 4 ratarata memiliki fault duration lebih dari 10 detik. Secara umum perangkat pengaman yang digunakan seperti sekering otomatis akan mengalami trip ketika fault duration lebih dari 1,5 detik. Tabel 6 menunjukkan data eksperimen yang mengalami fuse trip.

Tabel 6.

Data fuse trip pada eksperimen

\begin{tabular}{cccccc}
\hline $\begin{array}{c}\text { Percobaan } \\
\text { ke- }\end{array}$ & $\begin{array}{c}1 \\
\text { serabut }\end{array}$ & $\begin{array}{c}3 \\
\text { serabut }\end{array}$ & $\begin{array}{c}6 \\
\text { serabut }\end{array}$ & $\begin{array}{c}12 \\
\text { serabut }\end{array}$ & $\begin{array}{c}24 \\
\text { serabut }\end{array}$ \\
\hline 1 & Tidak & Tidak & Tidak & Tidak & Ya \\
2 & Tidak & Tidak & Tidak & Tidak & Tidak \\
3 & Tidak & Tidak & Tidak & Tidak & Ya \\
4 & Tidak & Tidak & Tidak & Ya & Ya \\
5 & Tidak & Tidak & Tidak & Ya & Tidak \\
\hline \hline
\end{tabular}

\section{Sinkronisasi data}

Untuk sinkronisasi data, dari citra statik yang didapatkan dari pengolahan menggunakan scene filter selanjutnya akan disesuaikan oleh grafik arus dan tegangan. Dalam tampilan antar muka nantinya akan diketahui bagaimana citra termal pada saat kontak, flash, dan debris. Dengan menggunakan band cursor dapat diketahui daerah toleransi saat terjadinya kontak sampai fault selesai. Hasil sinkronisasi data saat terjadi flash ditunjukkan oleh Gambar 4.
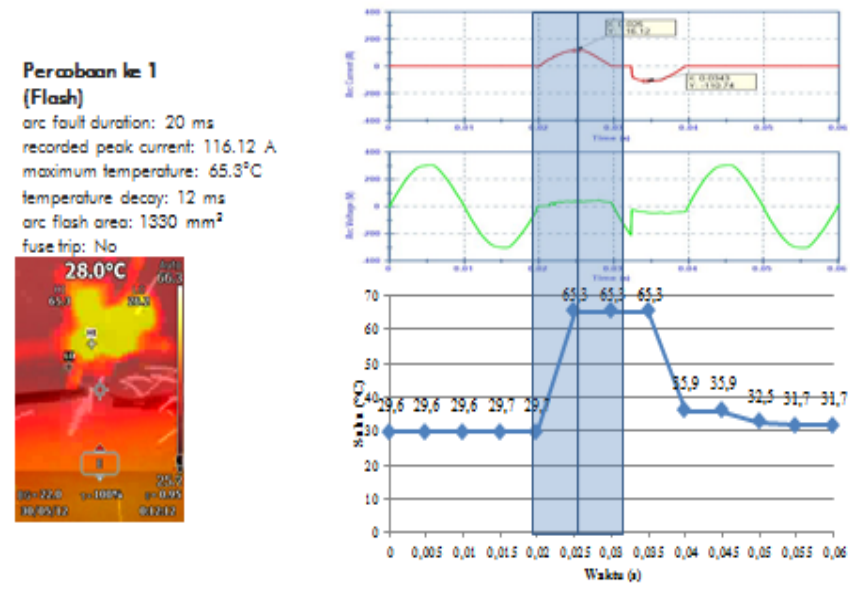

Gambar 4. Hasil sinkronisasi data saat terjadi flash

\section{KESIMPULAN/RINGKASAN}

Beberapa kesimpulan yang dapat diambil dari eksperimen dan analisis fenomena busur api listrik tegangan rendah pada kasus hubung singkat langsung melalui sinkronisasi penginderaan termal bunga api dan arus hubung singkat adalah sebagai berikut:

1. Variasi jumlah serabut pada eksperimen menunjukkan bahwa banyaknya serabut berpengaruh terhadap suhu maksimum dari busur api. Dari hasil eksperimen, suhu maksimum busur api dengan jumlah 1 serabut sebesar $69,8^{\circ} \mathrm{C}$ sedangkan dengan jumlah $3,6,12$, dan 24 serabut sebesar $>85^{\circ} \mathrm{C}$ dengan asumsi $>85^{\circ} \mathrm{C}\left(100^{\circ} \mathrm{C}\right)$.

2. Variasi jumlah serabut mempengaruhi ukuran luas dari busur api. Pada serabut 1, 3, dan 6, kontak antar serabut dapat maksimal karena jarak antar serabut renggang sehingga busur api yang terjadi maksimal. Sedangkan pada 12 dan 24 serabut, serabut semakin rapat sehingga busur api yang terjadi belum maksimal dan tertutupi oleh busur api yang lain. Dari hasil eksperimen, serabut dengan jumlah sedikit menghasilkan luas busur api yang besar sedangkan jumlah serabut banyak menghasilkan luas busur api kecil. Rata-rata ukuran luas busur api pada tiap serabut 1,3, dan 6 sebesar 446,4 $\mathrm{mm}^{2}, 634 \mathrm{~mm}^{2}$, dan 1126,2 $\mathrm{mm}^{2}$ sedangkan pada 12 dan 24 serabut sebesar $259,2 \mathrm{~mm}^{2}$ dan $380,2 \mathrm{~mm}^{2}$.

3. Banyaknya serabut yang mengalami kontak mempengaruhi terjadinya temperature decay period. Dari hasil ekperimen, rata-rata pada 1 serabut 2,48 milisekon, 3 
serabut 4,1 milisekon, 6 serabut 59,46 milisekon, 12 serabut 8505 milisekon, dan 24 serabut 8572 milisekon. Jumlah serabut banyak menyebabkan temperature decay period menjadi lebih lama dan memiliki potensi kebakaran sangat besar, karena suhu disekitar kabel menjadi lebih panas. Pada saat fault berakhir ternyata suhu pada jumlah serabut banyak semakin meningkat.

4. Variasi jumlah serabut berpengaruh terhadap nilai arus maksimum. Dari hasil eksperimen arus maksimum dengan jumlah 1 serabut sebesar 113,99 A, 3 serabut sebesar 115,01 A, 6 serabut sebesar 116,12 A, 12 serabut sebesar 127,78 A, 24 serabut sebesar 128,45 A. Arus yang besar ketika terjadi hubung singkat yang melewati satu serabut menyebabkan serabut melebur dengan cepat yang efeknya mempengaruhi durasi fault, begitu juga sebaliknya. Akibatnya, suhu meningkat dan meyebabkan melelehnya isolasi pada kabel.

5. Banyaknya jumlah serabut mempengaruhi fault duration. Dari hasil eksperimen, fault duration pada 1 serabut 9,8 milisekon, 3 serabut 17 milisekon, 6 serabut 174,2 milisekon, 12 serabut 2594,12 milisekon, dan 24 serabut 7,2 sekon. Busur api listrik dengan jumlah serabut sedikit menyebabkan meleburnya serabut secara cepat, sehingga fault duration menjadi singkat. Pada busur api listrik dengan jumlah serabut yang banyak, dimungkinkan serabut mengalami kontak kemudian menempel, sehingga durasi hubung singkat lebih lama, dan mengakibatkan fuse mengalami trip.

6. Respon dari pengaman instalasi tegangan rendah menunjukkan bahwa fuse otomatis mengalami trip dengan waktu > 1,5 detik, sehingga menyebabkan fault duration berlangsung lama.

\section{DAFTAR PUSTAKA}

[1] K.Mishra, A.Routray, and A. K. Pradhan, "Detection of Arcing in Low Voltage Distribution Systems", IEEE Region 10 Colloquium and the Third International Conference on Industrial and Information Systems 2008, pp. 1-3.

[2] National Fire Protection Association, "NFPA 70E: Standard for Electrical Safety in the Workplace", NFPA 2004.

[3] Badan Standarisasi Nasional. 2000. Persyaratan Umum Instalasi Listrik. Jakarta. BSN.

[4] Berdasarkan data Badan Nasional Penanggulangan Bencana (BNPB) periode Agustus 2011-2015.

[5] J.M. Martel, M. Anheuser, and F. Berger, "A Study of Arcing Fault in The Low-Voltage Electrical Installation”, IEEE 2010, pp. 1-11.

[6] Albert M. Smoak, P.E., Adam J. Keeth, "An Investigation of Low Voltage Arc Flash Exposure”, IEEE 2013, pp. 183-185.

[7] G. Artale, A. Cataliotti, V. Cosentino, and G. Privitera, "Experimental Characterization Of Series Arc Faults In AC And DC Electrical Circuits", 2014, pp. 1015-1020.

[8] N. K. Medora and A. Kusko, "Arcing Faults In Low And Medium Voltage Electrical Systems - Why Do They Persist?", 2011, pp. 1-6.

[9] E. Carvou, N. Ben Jemaa, S. Tian, Z. Belhaja, and B. Jusselin, "Electrical Arc Characterization For Ac-Arc Fault Applications", 2009, pp. 22-27.
[10] Lilley G. David, Lilley \& Associates, "Fire Causes and Ignition”, IEEE 1996, pp. 85-87.

[11] National Fire Protection Association, "NFPA Classification of Flammable and Combustible Liquids", NFPA 2006.

[12] Kolarić Darko, Lipić Tomislav, Grubišić Ivan, Gjenero Luko, and Skala Karolj, "Application of Infrared Thermal Imaging in Blade System Temperature Monitoring”, IEEE 2011, pp. 1-4. 